\title{
Female Genital Mutilation in Shii'a Jurisprudence
}

\author{
Seyed Mohammad Azin ${ }^{1 *}$ and Maedehsadat Kia ${ }^{2}$ \\ ${ }^{1}$ Department of Epidemiology and Reproductive Health, Royan Institute for Reproductive Biomedicine, Iran \\ ${ }^{2}$ MA student of law, Allame Tabatabaei University, Iran
}

Submission: March 05, 2018; Published: April 18, 2018

*Corresponding author: Seyed Mohammad Azin, Department of Epidemiology and Reproductive Health, Reproductive Epidemiology Research Center, Royan Institute for Reproductive Biomedicine, ACECR, Tehran, Iran, Email: azinlawyer@gmail.com

Abstract

Female genital mutilation is an ancient tradition which has been impregnated with myth and religious belief through millenniums. As a vast portion of its victims are Muslims, this study discusses whether there is a real Islamic rout in this tradition. The conclusion demonstrates a huge gap between current prevailing impression and real attitude of Islam especially Shii'a sect towards FGM.

Keywords: Female genital mutilation; Ancient tradition; Myth; Religious belief; Sunni Muslims; Shii'a; Abrahamic religions; Human rights; African; Jurisprudence; Surgery; Hijaz; Clitoridectomy; Clitoris; Sexual pleasure; Sexual relationship; Sanctity; Islamic view; Heavenly reward; Oppression; Human values; Islamic quotations; Cautiousness; Morality

\section{Opinion}

Female genital mutilation has a lengthy history among populations. According to a quotation attributed to Imam Ali (first Imam of Shii'a and fourth Imam of Sunni Muslims) the first one who ordered male mutilation was Abraham the prophet, who commanded his wife Sarah to do mutilation for their son Isaac [1]. So, in parallel with male mutilation which developed in Abrahamic religions due to his order, female genital mutilation, although lacked any religious binding law, became popular. Nowadays, female genital mutilation still takes place all over the world, especially in African developing countries despite increasing waves of objection among human rights experts and law and ethics specialists [2]. This short manuscript aims at studying whether Female Genital Mutilation (FGM) has a religious powerful support or not. As the main countries carrying out FGM have different portions of Muslims, this paper focuses on Islamic perspective regarding FGM and seeks details of Shii'a jurisprudence as one of the main sects in Muslim world with about 400 million populations worldwide.

First of all, it is considerable that context of quotations attributed to Shii'a Imams (Leaders) proves that when Islam emerged (7th to 9th century A.D) FGM was a common surgery among female children as well as male ones at Hijaz (recognized as Saudi Arabia after world war I). Therefore, it is not surprising to find some quotations permitting FGM at that time. However, in these statements there is not any sign of sanctity for FGM, but contrarily in one statement, interests of future couple to have pleasant sexual relationship is mentioned as the cause of FGM authorization [3]. This permission is limited to partial clitoridectomy which involves partial removal of the clitoris and thus, it does not seek depriving female from sexual pleasure, but also according to Shirazi, the aim of FGM is to provide the couple with more successful sexual relationship. Sanctity requires compulsion but as mentioned above, FGM is not regarded obligatory according to all Muslim jurists including Shii'a clerics [4]. The mandatory mutilation is exclusively male mutilation which even itself has a critic among Shii'a jurists. Even though it constitutes minority viewpoint to deny male mandatory mutilation, it becomes totally different when we discuss FGM. As stated before, there is no compulsive rule imposing FGM to Muslim women, although some believe in its beneficence [5].

In some quotations attributed to Shii'a Imams, it is suggested that FGM takes place when the girl reaches 7 years old. Hence, FGM before this age is not regarded as beneficent in Islamic view. This is one other sign to receive this message that Islam does not permit any harm to female subject of mutilation and to protect female child, postpones it until she reaches [6]. According to a Shii'a thinker, the ruler has no authority to coerce a girl to have FGM. Considering an evident Islamic law which legitimates wide authority for ruler in society and father in family, beside decreasing authority of both over the society-family members currently, concludes that nowadays, it is not in father's discretion to decide about her daughter's FGM. So, it seems that any imposed 
FGM without girl's consent should be forbidden and considering non-sacred nature of FGM, it is the girl herself who has to decide provided she becomes mature and enjoys full capacity [7].

Despite some current thought which recognizes reward for FGM in other world, a quotation of 6th Imam of Shii'a acknowledges that FGM is not a part of "Sunna" i.e., it is not obligatory nor recommended as a religious act which is expected to lead to heavenly reward. Moreover, a contemporary Shii'a cleric states: "If FGM is not a recommended religious act (=Mustahab), it must be regarded as an oppression to girl's rights". He adds: "Islam authorized FGM only because it was not due time to interdict it and (the best solution) was to let this custom be abandoned gradually by the society itself" [8]. A simultaneous consideration of Shii'a jurists from emergence of Islam until now, clearly demonstrates decreasing trend to authorize FGM. We even face that some contemporary Shii' a jurists refuse to answer their followers' questions about recommendation of FGM in Islam and by this cautious silence, this message is clearly heard that Islam, especially Shii'a perspective does not recognize FGM as a religious matter at all. In other words, current trend of Shii'a school, denies Islamic recommendation of FGM but refers it to category of beauty surgeries which requires other conditions including girl's informed consent after acquiring full capacity i.e., achievement of enough power of rational discretion which is naturally impossible to occur at childhood [9-13].

As considered above, Islamic attitude, especially Shii'a way of thought is dramatically different from common knowledge even among Muslims themselves. It is may be the shadow of ignorance even among specialists which masks face of truth. Religious reference texts, including Islamic quotations enjoy wide range of tolerance and the authors deeply believe that by more cautiousness, more cleverness and more responsibility toward human values, we will definitely witness less conflicts among religious teachings and current rationally admired life styles. This orientation is totally compatible with a famous quotation from prophet Mohammad who calls his mission as "to attain the peak of morality".

\section{References}

1. Hosein Bahrani (1216 Islamic calendar or A.H $=1802$ A.D) Al-Anvar Al-Lavame, Majma Al-bohuth Al-elmiah, Qom 2: 293

2. https://www.prb.org

3. Mohammad Koleini (1407 A.H = 1987 A.D) Al-Kafi, Dar Al-kotob Alislamiah, Tehran 6(6): 38.

4. Seyed Sadegh Hoseini Shirazi (1428 A.H $=2007)$ Alf Masalah fi Belad Al-gharb, Dar Al-oloum, Beirut, Pp.289

5. Naser Makarem (1426 A.H = 2005) Ahkam Al-Nesa, Madrese Imam Ali Publication, Qom, p.199

6. https://link.springer.com/content/pdf/bbm\%3A978-1-349-178568\%2F1.pdf

7. Yusof Bahrani (1405 A.H = 1985) Al-Hadaegh Al-Nazera, Islamic publication office, Qom, 25: 50

8. Mohammad Fazel Lankarani (1421 A.H = 2001) Tafsil Al-Sharia fi Sharh Tahrir Al-vaslia, Aemme Athar juridicial center, Qom, Pp.533

9. Abolghasem Qomi (Mirza Qomi) (1413 A.H = 1993) Jame Al-shetat Kayhan Publication, Tehran, 4: 614

10. Seyed Mohammad Sadr, Mavara Al-fiqh, Dar Al-Azva, Beirut (1420 A.H $=2000$ ) A contemporary jurist proves prohibition of FGM based on No-Harm argument in Islam which forbids any kinds of ethically unjustified harm to others 6: 223.

11. Javad Tabrizi (1427 A.H =2006) Serat Al-najat, Dar Al-Sedigha AlShahida, Qom, 9: 299.

12. Naser Makarem (1424 A.H = 2004) Ketab Al-nekah, Madrese Imam Ali Publication 6: 81

13. Hosein Mohaddes Nouri (1408 A.H = 1988) Mostadrak Al-vasael, Al AlBayt Institution, Beirut, 11: 187.

\section{Your next submission with Juniper Publishers will reach you the below assets}

- Quality Editorial service

- Swift Peer Review

- Reprints availability

- E-prints Service

- Manuscript Podcast for convenient understanding

- Global attainment for your research

- Manuscript accessibility in different formats

( Pdf, E-pub, Full Text, Audio)

- Unceasing customer service

Track the below URL for one-step submission

https://juniperpublishers.com/online-submission.php 